Шумкова О. В., к.е.н., доцент

Шумкова В. I., к.е.н., старший викладач Сумський національний аграрний університет м. Суми, Україна

DOI: https://doi.org/10.30525/978-9934-26-036-0-19

\title{
ВИКОРИСТАННЯ МАРКЕТИНГОВИХ МОЖЛИВОСТЕЙ ТА СИЛЬНИХ СТОРІН ПІДПИЕМСТВА ДЛЯ ВДОСКОНАЛЕННЯ ЙОГО МАРКЕТИНГОВОЇ ДІЯЛЬНОСТІ
}

Політична та економічна нестабільність, ризиковий характер підприємницької діяльності у сфері оборони, підвищення ролі конкуренції як на державному так і на комерційному ринках призводить до того, що підприємству необхідно постійно підвищувати ефективність управління його діяльністю у цілому та маркетинговою діяльністю зокрема.

Одним із способів підвищення ефективності саме управління маркетинговою діяльністю є визначення основних маркетингових можливостей діяльності підприємства та розробка на їх основі головних стратегій для реалізації таких можливостей 3 подальшим розвитком підприємства та реалізації його основних цілей $[1$, с. 72$]$.

Аналіз маркетингових можливостей та їх подальший вплив на розвиток маркетингової діяльності було проведено на основі даних Державного підприємства «Конотопський авіаремонтний завод «Авіакон», яке розташоване за адресою: Сумська область, місто Конотоп і спеціалізується на капітально-відновлювальному ремонті, переобладнанні та модернізації вертольотів Мі-6, Mi-2, Mi-8, Мi-17, Мi-24, Мi-35 і Мi-26 всіх модифікацій та їх обладнанні [3].

Під час визначення основних маркетингових можливостей діяльності підприємства було приділено увагу таким особливостям його діяльності, а саме: 
- невелика кількість ризиків діяльності підприємства та наявність достатніх ресурсів для подолання їх негативного впливу (за потреби);

- кількість конкурентів на внутрішньому та зовнішньому ринку є незначною, адже у більшості випадків ці підприємства налають послуги з ремонту та обслуговування однієї або двох моделей літальних апаратів;

- наявність чітко визначених сегментів на ринку та груп постійних і перспективних клієнтів як на внутрішньому так і на зовнішньому ринках;

- наявність постійних державних замовлень;

- значний рівень підтримки підприємства з боку держави.

Під час дослідження маркетингових можливостей підприємства i їх вплив на подальший розвиток системи управління маркетинговою діяльністю було використано метод SNW-аналізу. На основі даного методу проводиться сукупна оцінка підприємства, яка відображає його сильні, слабкі і нейтральні сторони. 3 його використанням можливо визначити конкурентоспроможність підприємства, при якому в ролі нейтральної позиції найкраще вибрати середній ринковий стан для конкретної ситуації [2]. SNW-аналіз діяльності підприємства представлено в таблиці 1.

Таблиця 1

SNW-аналіз діяльності Державного підприємства «Конотопський авіаремонтний завод «Авіакон»

\begin{tabular}{|c|c|c|c|}
\hline Фактори & $\begin{array}{c}\text { Сильні } \\
\text { сторони (S) }\end{array}$ & $\begin{array}{c}\text { Нейтральні } \\
\text { сторони (N) }\end{array}$ & $\begin{array}{c}\text { Слабкі } \\
\text { сторони (W) }\end{array}$ \\
\hline 1 & 2 & 3 & 4 \\
\hline $\begin{array}{c}\text { Обрана стратегія розвитку } \\
\text { підприємства }\end{array}$ & + & & \\
\hline $\begin{array}{c}\text { Висока конкурентоспроможність } \\
\text { підприємства }\end{array}$ & + & & \\
\hline $\begin{array}{c}\text { Досвід роботи підприємства на відпо- } \\
\text { відному ринку продукції (послуг) }\end{array}$ & + & & \\
\hline $\begin{array}{c}\text { Можливість створення та реалізації } \\
\text { унікальних товарних пропозицій }\end{array}$ & + & & \\
\hline
\end{tabular}


Продовження Таблиці 1

\begin{tabular}{|c|c|c|c|}
\hline 1 & 2 & 3 & 4 \\
\hline Фінансове становище підприємства & & + & \\
\hline Сертифікованість продукції & + & & \\
\hline Досвід роботи працівників & + & & \\
\hline Корпоративна культура & & & + \\
\hline Рівень мотивації працівників & & & + \\
\hline Інфраструктура підприємства & & & + \\
\hline $\begin{array}{c}\text { Стан матеріального забезпечення } \\
\text { підприємства }\end{array}$ & & + & \\
\hline $\begin{array}{c}\text { Стан інформаційного забезпечення } \\
\text { підприємства } \\
\end{array}$ & & + & \\
\hline $\begin{array}{c}\text { Стан технологічного забезпечення } \\
\text { підприємства }\end{array}$ & + & & \\
\hline Рівень доступу до нових технологій & & + & \\
\hline $\begin{array}{l}\text { Приналежність підприємства до } \\
\text { концерну УКРОБОРОНПРОМ }\end{array}$ & & + & \\
\hline Всього & 7 & 5 & 3 \\
\hline
\end{tabular}

Наступним кроком є виділення факторів, які впливають на позиції авіаремонтного заводу щодо реалізацій маркетингових можливостей (зміцнюючи позиції та послаблюючи позиції), та розділення їх на ті, що описують сильні та слабкі сторони підприємства за результатами проведеного SNW-аналізу (табл. 2).

Таблиця 2

\section{Виділення факторів, що впливають на впровадження можливостей підприсмства за даними SNW-аналізу}

\begin{tabular}{|c|c|}
\hline Фактори, що описують сильні сторони & $\begin{array}{c}\text { Фактори, що описують } \\
\text { слабкі сторони }\end{array}$ \\
\hline 1. Обрана стратегія розвитку підприємства & 1. Корпоративна культура \\
\hline 2. Висока конкурентоспроможність підприємства & $\begin{array}{l}\text { 2. Рівень мотивації } \\
\text { працівників }\end{array}$ \\
\hline $\begin{array}{l}\text { 3. Досвід роботи підприємства на відповідному } \\
\text { ринку продукції (послуг) }\end{array}$ & $\begin{array}{l}\text { 3. Інфраструктура } \\
\text { підприємства }\end{array}$ \\
\hline $\begin{array}{l}\text { 4. Можливість створення та реалізації } \\
\text { унікальних товарних пропозицій }\end{array}$ & - \\
\hline 5. Сертифікованість продукції & - \\
\hline 6. Досвід роботи працівників & - \\
\hline $\begin{array}{l}\text { 7. Стан технологічного забезпечення } \\
\text { підприємства }\end{array}$ & - \\
\hline
\end{tabular}


Дані таблиць 1 та 2 свідчать, що підприємство має переважну більшість сильних сторін, у порівнянні зі слабкими сторонами у діяльності. Але також слід констатувати, що у підприємства $є$ велика кількість нейтральних сторін діяльності, які доцільно перетворити у маркетингові можливості, а в подальшому, і в сильні сторони діяльності підприємства.

Таким чином, на основі проведених досліджень, можна виділити такі стратегічні напрямки розвитку маркетингових можливостей підприємства:

- покращення фінансового становища для забезпечення належного матеріального та інформаційного розвитку підприємства;

- розвиток інфраструктури підприємства;

- зміцнення зв'язків авіаремонтного заводу з іншими підприємствами концерну УКРОБОРОНПРОМ;

- залучення іноземних інвесторів для фінансування розробок нових технологій у галузі авіабудування та авіаремонту.

Отже, представлені вище заходи допоможуть підприємству ефективного використати свої можливості та сильні сторони для вдосконалення його подальшої маркетингової діяльності.

\section{Література:}

1. Бойчук І.В. Організація маркетингової діяльності на промислових підприємствах. Торгівля, комерція, підприємництво. 2018. № 17. С. 71-74.

2. Гордієнко О.В. Удосконалення організації маркетингової діяльності підприємств. URL: http://journals.khnu.km.ua/vestnik/pdf/ekon/2011_2_2/156160.pdf (дата звернення: 10.02.2021).

3. Офіційний сайт Державного підприємства «Конотопський авіаремонтний завод «Авіакон». URL: http://www.aviakon.com (дата звернення: 09.02.2021). 